\title{
Extracellular Vesicles as Delivery Vehicles of Specific Cellular Cargo
}

\author{
Bilal Mir and Claudia Goettsch * (B) \\ Department of Internal Medicine I, Cardiology, Medical Faculty, RWTH Aachen University, \\ 52074 Aachen, Germany; bmir@ukaachen.de \\ * Correspondence: cgoettsch@ukaachen.de; Tel.: +49-241-80-37312
}

Received: 8 June 2020; Accepted: 30 June 2020; Published: 2 July 2020

check for updates

\begin{abstract}
Extracellular vesicles (EVs) mediate cell-to-cell communication via the transfer of biomolecules locally and systemically between organs. It has been elucidated that the specific EV cargo load is fundamental for cellular response upon EV delivery. Therefore, revealing the specific molecular machinery that functionally regulates the precise EV cargo intracellularly is of importance in understanding the role of EVs in physiology and pathophysiology and conveying therapeutic use. The purpose of this review is to summarize recent findings on the general rules, as well as specific modulator motifs governing EV cargo loading. Finally, we address available information on potential therapeutic strategies to alter cargo loading.
\end{abstract}

Keywords: extracellular vesicles; cargo loading

\section{Introduction}

Communication between cells is essential to a biological system. Cell-derived signals, via direct cell-to-cell interaction or cell signaling molecules, influence recipient cells' energetics, biosynthesis and even survival. The transfer of information by extracellular vesicles (EVs) emerges as an additional platform for delivering biomolecules and signals to cells of the surrounding tissues. The presence of EVs in the human body was detected several decades ago, but their sphere of action has not been wholly elucidated until today. The term "extracellular vesicles" describes a heterogeneous class of cell-derived vesicles of different origins, which decelerates the progress of identifying their nature. The originating cell type seems to impact the composition of EVs. Furthermore, several intracellular compartments are involved in sorting and formation processes, which causes additional diversity.

Growing interest in EV biology emerges from results that implicate a crucial role in the progression of several diseases. Interestingly, EVs are a double-edged sword, given their dual role throughout the body in physiological and pathological conditions (reviewed in Mc Gough et al. 2016) [1]. For example, they contribute to the immune response against pathogens or tumor cells, by transferring antigen-loaded major histocompatibility complex II (MHC II) between immune cells [2,3]. In contrast, they are utilized by several viruses for spreading and survival strategy (reviewed in [4]). They can be a carrier of epidermal growth factor (EGF) and its receptor, resulting in improved wound healing after injuries [5], but these EVs also stimulate tumor growth [6]. In addition, cancerous cells benefit from the RNA transport function of EVs, which causes reprogramming and tumor expansion in surrounding cells [7]. In neurodegenerative diseases like Alzheimer's disease, EVs are linked to the spreading of misfolded proteins [8]. Conversely, by supporting communication between oligodendrocytes and neurons, they are beneficial for the integrity of the central nervous system, [9]. This interaction is essential for neuronal survival. EVs are reported as tools of communication between bone cells, and seem to be involved in the regulation of osteoclast and osteoblast balance by RNA transfer [10]. Yet, they can also initiate microcalcification in vascular or valvular tissue [11], which can result in myocardial infarction 
or calcific aortic valve disease. These aspects combine to make EVs a topic of huge interest for current medical research. Further investigations of EV biology could provide the opportunity to develop new therapeutic strategies that may contribute to overcoming diverse diseases.

This review provides an overview of the current state of knowledge of EV subtypes and their life cycles. To understand how EVs function, it is crucial to investigate the cargo sorting process, the EV trafficking and the release mechanisms as far as the uptake by recipient cells. We analyze how an altered cargo influences disease progression, particularly in the context of cardiovascular calcification. We also provide an overview of molecules to alter EV release, which could harbor a potential therapeutic strategy.

\section{Heterogeneity of Extracellular Vesicles (EVs)}

EVs are a heterogeneous group, with still no clear characterization of the particular subtypes. Defined criteria for distinguishing EV subtypes are still lacking, with numerous terms in use to describe EVs-exosomes, microvesicles, oncosomes, prostasomes, argosomes, membrane particles, are some of the many names to appear in different publications (reviewed in [12]). At the first annual meeting of the "International Society for Extracellular Vesicles" (ISEV) in 2012, researchers broached the difficulty of a uniform nomenclature, but could not reach a consensus. Traditionally classified into so-called exosomes, microparticles, and apoptotic bodies, only the expression "extracellular vesicles" was defined as a general term for all naturally released cellular vesicles with a lipid bilayer and without a nucleus and thus replication $[13,14]$.

Exosomes are formed by the budding inward of the lumen of endosomes/multivesicular bodies (MVBs) as intraluminal vesicles (ILVs). MVBs are designated to fuse with the cell membrane to release their ILVs to the extracellular space, or can fuse with lysosomes for subsequent degradation. Originally, exosomes were described to reach a size ranging from 0.03 to $0.15 \mu \mathrm{m}$ in diameter, but recently a size up to $0.25 \mu \mathrm{m}$ was reported [15]. Tetraspanins (cluster of differentiation (CD) 9, CD63, CD81), the tumor susceptibility gene 101 (TSG101) and syntenin-1 are suggested as specific markers for EVs of endosomal origin [16], although this remains under debate. Additionally, small $(<50 \mathrm{~nm})$ extracellular non-membranous nanoparticles named exomeres, which can easily be mistaken as exosomes, have been described recently [17]. They contain metabolic enzymes and are enriched in Argonaute (Ago) proteins [18].

Microparticles, also known as "microvesicles", "shedding vesicles", or "ectosomes", vary in size from 0.1 to $1 \mu \mathrm{m}$ in diameter. Unlike exosomes, they are characterized by budding directly from the cell's plasma membrane following phospholipid rearrangement between the inner and outer leaflet [19]. This differing origin compared to exosomes prompted the assumption that another functionality and further effects may be involved. CD29, CD44 [20], C1q and the yeast protein TyA are documented as specific microparticle markers [21]. Recently, Jeppesen et al. revealed Annexin A1 to be expressed more frequently in larger vesicles without tetraspanin expression [22]. The release of both EV subtypes is enhanced by increased intracellular $\mathrm{Ca}^{2+}$, given that calcium-dependent enzymes are involved in the formation process [23].

Apoptotic bodies are built by blebbing from the cell membrane during apoptotic disassembly processes [24]. These reach sizes from 1 to $5 \mu \mathrm{m}$ [25] and present another option to transfer molecules and signals to surrounding cells and could thus prevent further disease progression. Annexin V, which is a marker for apoptosis, is also enriched in apoptotic bodies [26].

The classification of EVs into microparticles and exosomes was challenged since vesicles with a diameter in the supposed range of microparticles, but with exosomal markers, were detected [12]. This review uses the terms "exosome" and "microparticle" to describe only the findings that can be related to the specific origin of EVs in accordance with the guidelines of the ISEV. Recent publications distinguish large EVs (lEVs) gathered as an ultracentrifugation pellet at $15,000 \times g$ speed, from small EVs (sEVs) that can be detected in $120,000 \times g$ pellets [22]. Typical common EV markers are heat shock proteins (HSP70, HSC70, HSP90) and flotillin-1 [16]. EVs can be isolated by several methods (reviewed 
in [27-29]) like differential centrifugation, density gradient separation, precipitation-based isolation or size-exclusion chromatography. Flow cytometry can be used to characterize only larger EVs, or by using antibodies which are bound to larger beads [30-32].

Various pathways within the cell influence EV composition and may generate additional EV subpopulations. Furthermore, the EV membrane and cargo seem to differ based on the originating cell type [33]. EV research is not very transparent, with many publications from different research areas. This mass of information has spawned multiple online databases-Vesiclepedia (www.microvesicles.org), EVpedia (www.evpedia.info) and ExoCarta (www.exocarta.org) provide information about protein, lipid and nucleic acid composition in EVs, while EV-Track is a website which offers the possibility to exchange information, share experience or seek advice relating to EV research.

\section{Mechanism of Cargo Sorting into EVs}

EVs can contain a broad spectrum of biomolecules, as described in the following section. For cargo sorting into EVs, different sorting pathways have been described in past decades. Table 1 provides an overview of these mechanisms, most of which are somehow interlinked.

Table 1. Extracellular vesicle (EV) cargo loading machineries and their reported targets.

\begin{tabular}{ccc}
\hline Cargo Sorting Machinery & Reported Cargo & References \\
\hline ESCRT-complex & proteins (ubiquitin-tagged) & {$[34]$} \\
Ubiquitin Binding Proteins (ISG15, UBL3) & proteins (ubiquitin-tagged) & {$[35,36]$} \\
plix (ESCRT-III associated) & ubiquitin-independent) & {$[37]$} \\
Alix-Syntenin-Syndecan-complex & proteins (binding to heparanase sulfate) & {$[38]$} \\
(Phospholipase D2-ARF6-regulated) & proteins (Nedd4 family members or & {$[39,40]$} \\
Ndfip1 & WW-tagged) & {$[41]$} \\
sphingosine-1-phosphate and receptor & proteins (transferrin receptor, CD63) & {$[42,43]$} \\
Tetraspannins (CD9, CD63) & proteins (specifically interacting) & {$[44]$} \\
ARRDC1-Vps4/TSG101 & proteins (microparticle exclusive) & {$[45,46]$} \\
lipid raft associated sorting & proteins & {$[47]$} \\
sumoylated SYNCRIP & miRNA (EXOmotif) & {$[48]$} \\
Alix-Ago2 & miRNA & {$[49]$} \\
KRAS & miRNA & {$[50]$} \\
YBX1 & miRNA & {$[51]$} \\
HuR & miRNA & {$[52]$} \\
proteins) & miRNA & {$[53]$} \\
unknown & non-coding RNA & {$[54]$} \\
unknown & mtDNA & {$[55,56]$} \\
\hline Lc3b-machinery (associated to RNA binding & mineral &
\end{tabular}

Ago: Argonaute, ALIX: ALG-2-interacting protein X, ARF6: ADP ribosylation factor 6, ARRDC1: Arrestin domain-containing protein 1, CD: Cluster of differentiation, DNA: Deoxyribonucleic acid, ESCRT: Endosomal sorting complex responsible for transport, hnRNPA2B1: Heterogenous nuclear ribonucleoprotein A2B1, HuR: Human antigen R, ISG: Interferon-stimulated gene, KRAS: Kirsten rat sarcoma, Lc3b: Microtubule-associated protein 1 light chain $3 \beta$, miRNA: micro RNA, mtDNA: mitochondrial DNA, Ndfip1: Nedd4 family-interacting protein 1, Nedd4: Neural precursor cell expressed developmentally down-regulated protein 4, RNA: Ribonucleic acid, SYNCRIP: Synaptotagmin binding cytoplasmic RNA interacting protein, TSG101: Tumor susceptibility gene 101, UBL: Ubiquitin-like protein, Vps: Vacuolar protein sorting, YBX1: Y-box protein 1.

\subsection{Pathways of Protein Sorting}

The functionality and destination of EVs differ due to a variation of loaded components, which also modify their membrane composition. Alterations in EV cargo demonstrate influence on disease progression; therefore, cellular components and mechanisms determining the loading process need to be elucidated. The ESCRT (Endosomal Sorting Complex Responsible for Transport) machinery was identified in the context of sorting ubiquitinated proteins into vesicles [34]. While possibly the best 
examined pathway of EV cargo sorting, it has been known for years that EV formation does not rely on one specific mechanism and alternative pathways exist.

The ESCRT machinery contains four multi-protein complexes (ESCRT-0/-I/-II/-III) and additional accessory proteins (reviewed in [57]). These can be subdivided into early acting complexes (ESCRT-0/-I/-II) - mainly involved in ubiquitinated cargo sorting — and late acting components (ESCRT-III and vacuolar protein sorting 4 (Vps4)), which terminate EV formation and budding (reviewed in [58]). The early acting ESCRT complexes recruit each other and contain specific ubiquitin-binding domains (UBDs). Studies suggest that ESCRT-0 self-associates at the membrane of endosomes [59] by interacting with its subunit hepatocyte growth factor-regulated tyrosine kinase substrate (Hrs with FYVE-domain) and the phospholipid phosphatidylinositol 3-phosphate (PI3P), which is abundant in the early endosomal membrane [60]. Then, the Hrs compartment interacts with the tumor susceptibility gene 101 (TSG101), which is part of the ESCRT-I protein complex [61]. This complex leads to the assembly of ESCRT-II through Vps28 (ESCRT-I)-Vps36 (ESCRT-II) interaction. Both ESCRT-I and -II contain UBDs for protein recruitment. Several ESCRT proteins can oligomerize and thereby achieve a high avidity, given that they reveal only a modest affinity as monomers [62]. At late stage, the ESCRT-III complex is recruited and activated by Vps25 (ESCRT-II)-Vps20 (ESCRT-III) interaction [63]. ESCRT-III plays a crucial role in EV formation by initiating membrane deformation and inward budding. Its filaments polymerize and form a spiral-like belt, enwrapping the vesicle (reviewed in [58]). ATPase Vps4 is involved in the disassembly of the ESCRT-III complex. Until now, the mechanism behind the formation has not been completely understood. It is known, that the ESCRT machinery is recycled before the budding process is completed [64], and that the cargo loses its ubiquitin-tag prior to vesicle scission via the de-ubiquitinating enzyme-associated molecule with the SH3 domain of STAM (AMSH) [65].

In this ESCRT-conducted process, additional interacting proteins are described that take part in EV cargo loading. Neural precursor cell expressed developmentally down-regulated protein 4 (Nedd4) family-interacting protein 1 (Ndfip1) is an endosomal adaptor protein detected in EVs. Besides loading of Nedd4 family proteins into EVs, it can further recruit ubiquitinated proteins labelled with a WW-tag $[39,40]$. Another important ESCRT-accessory protein is ALG-2-interacting protein $X$ (Alix), which is recruited by charged multivesicular body protein 4a (CHMP4) [66], a subunit of ESCRT-III. This binding leads to a stabilization of the complex. In addition to the ESCRT-I component TSG101, Alix is one of the most abundant proteins in exosomes and widely used as a marker. Alongside its widespread involvement in membrane remodeling processes, Alix can act like an adaptor protein that recruits cargo into developing EVs, in an ubiquitin-independent manner [37,67]. This recruitment was described for G-protein coupled receptor protease activated receptor 1 (PAR1) [37] and the purinergic receptor P2Y1 [67], which are both transferred to the MVB membrane by recognition of their $\mathrm{YPX}_{3} \mathrm{~L}$-motif and the transferrin receptor [68]. Alix is also involved in miRNA recruitment by interaction with the protein complex Argonaute 2 (Ago2) [49]. In addition, it enriches lysobisphosphatidic acid (LBPA) within the prospective EV membrane [69], which is involved in the membrane deformation process, and was suggested as initiator of an additional recruitment pathway by interacting with syntenin, the cytoplasmic adaptor protein. Syntenin binds syndecan and other proteins via their PDZ domain [70]. The Alix-syntenin-syndecan complex, which was described to control around $50 \%$ of vesicles in MCF-7 cells [71], can sort specific cargo into EVs. In particular, the syndecan domain heparan sulfate seems to be involved in the sorting and formation process which is cleaved and activated by the modulator-enzyme heparanase [38].

Depletion of all four ESCRT-components does not completely prevent ILV formation within MVBs [72], suggesting the existence of ESCRT-independent loading processes. One of the alternative pathways is tetraspanin-dependent. For example, CD63 stabilizes the pre-melanonsome protein (PMEL) in vesicles during melanogenesis [43]. CD9 interacts with the metalloproteinase CD10 [42] and causes an enhanced EV release. It has been noticed that ESCRT-independent vesicles are smaller than ESCRT-dependent, given that depletion of CD63 causes only a decrease of smaller vesicles $(<40 \mathrm{~nm})$ [73]. 
Posttranslational modification by ubiquitin-like proteins (UBLs) seems to be another mechanism to influence EV release and protein recruitment. Interferon-stimulated gene 15 (ISG15) is an UBL protein, inducible by interferons (IFN) [35]. This ISGylation causes the accumulation and degradation of TSG101, resulting in impaired exosome secretion and potentially, subsequent alterations in EV cargo. In addition, UBL3-modification is involved in the protein sorting process of smaller EVs [36].

Less is known about the cargo loading mechanisms of EVs budding directly from the cell membrane. It has long been assumed that the composition of microparticles reflects the cell of origin and the loading process is just passive. However, components of the ESCRT machinery also appear to be involved in the protein sorting of this EV type, although they are directly released and are not intended for lysosomal degradation. The ESCRT-associated ATPase Vps4, as well as TSG101, are reported to play an important role in protein recruitment here [44]. Their interaction with Arrestin Domain-Containing Protein 1 (ARRDC1), which is bound to the plasma membrane, induces relocation of TSG101 via ubiquitin E2 variant (UEV)-motif recognition from the endosomal membrane [44]. The released microparticles are ARRDC1 ${ }^{+}, \mathrm{TSG}_{101}{ }^{+}$, but lack tetraspanins [22].

\subsection{The Role of Lipids in EV Formation}

EVs consist of a lipid bi-layer, given their origin from the plasma or endosomal membrane. Specific lipids are enriched in EVs and may contribute to the sorting and formation process. The membrane of microparticles does not show significant differences in its lipid composition compared to the originating cell membrane [61]. In contrast, the membrane of exosomes is enriched in sphingolipids, glycerophospholipids, ceramide, and cholesterol [74]. The cholesterol content of the endosomal membrane may influence the fate of the arising EVs. While exosomes originating from cholesterol-rich MVBs are determined for secretion, a low cholesterol level directs MVBs to lysosomal degradation $[57,75]$. EV membrane analysis by Harada et al. revealed at least three different membrane types: low density detergent-insoluble membranes, detergent soluble membrane, and the flotillin-1 enriched high density detergent-insoluble membranes. They identified proteolysis of A disintegrin and metalloproteinase domain-containing protein 10 (Adam 10) and hepatocyte growth factor receptor Met as possible triggers for membrane type switching and thus, alterations in the EV sorting process [76]. Specific membrane domains in the MVB membrane, enriched in cholesterol, sphingolipids and glycosylphosphatidylinositol (GPI)-anchored proteins, are called lipid rafts. MHC II, $\alpha$ B-crystallin or flotillin-1 are examples of raft-associated proteins $[45,46]$ recruited by lipid raft interaction and present in EVs. Furthermore, proteolipid protein (PLP) is abundant in oligodendroglial precursor cell-derived EVs [74] and may contribute to the membrane structure. PLP-containing EVs revealed a similar lipid composition to lipid rafts. Additionally, the release of PLP-enriched EVs is not impaired after silencing of ESCRT-associated proteins [74], suggesting that PLP is part of an ESCRT-independent ILV-forming machinery.

The neutral sphingomyelinase 2 (n-SMase 2) plays a key role in EV formation, since its inhibition effectively reduces EV release in general, as well as specifically PLP-enriched EVs [74]. The n-SMase 2 converts sphingomyelin in ceramide [1], which is a membrane lipid that deforms membranes, thereby initiating the inward budding process. Its further metabolization into sphingosine-1-phosphate and its receptor is associated with an advanced maturation process and an ESCRT-independent cargo sorting [41]. This involves for example tetraspannin, the transferrin receptor and CD63, which itself is described further on here as a recruiter. The inhibition of phospholipase D2 also decreases EV secretion [77]. It converts lyso-phosphatidic acid into phosphatidic acid, a cone-shaped lipid, involved in the budding process of endosomes and, together with the small GTPase ADP ribosylation factor 6 (ARF6), regulates syntenin and probably the subsequent cargo loading pathway [78].

\subsection{Transfer of RNA between Cells}

It has been several years since any RNA species were identified as EV cargo, but the mechanisms behind the sorting have yet to be fully elucidated. Directed sorting is assumed, due to publications 
demonstrating differences in microRNA (miRNA) composition between EVs and their cell of origin [50,79]. Besides messenger RNA (mRNA) and miRNA, additional non-coding RNA types like ribosomal RNA (rRNA), transfer RNA (tRNA), Y-RNA and large intergenic noncoding RNA (lincRNA), were found enriched in EVs [22,80]. Not only are recipient cells able to take up these RNAs, but moreover, an adjacent functionality has been proven [81].

In human liver stem-like cells the adaptor protein Alix was identified to control EV RNA loading [49]. Alix recruits the RNA-binding protein Ago2 to the endosomal membrane, resulting in miRNA binding and subsequent packaging into EVs. Ago2 is part of the RNA-induced silencing complex (RISC). Both it and the endoribonuclease Dicer are RNA-processing enzymes which have been detected within EVs [82]. Depletion of ESCRT components revealed a decrease of miRNA-mediated gene silencing, changing the image of EVs as bare vehicles to RNA regulation sites [83]. Recent work attributes involvement in miRNA sorting to the Y-Box Protein 1 (YBX1) [51]. Sorting activities were observed in vitro; the explicit mechanism merits further investigation. Additional candidates for miRNA loading are Kirsten Rat Sarcoma (KRAS) [50] and ELAV-like protein 1/human antigen R (HuR) [52].

A short sequence, termed EXOmotif, was detected in miRNAs that are designated as EV cargo [47]. The ubiquitously expressed heterogenous nuclear ribonucleoprotein A2B1 (hnRNPA2B1) binds to an RNA transport signal (RTS) at the $3^{\prime}$ untranslated region (UTR) of the miRNA, containing this motif. This interaction relocates the miRNAs to the EV formation site [47]. Furthermore, hnRNPA2B1 co-localizes with ceramide, the product of the n-SMase [47]. The observation, that n-SMase inhibition caused a miRNA reduction in EVs [84] supports involvement of these factors in the EV miRNA sorting process. Recent evidence suggests that post-translational modifications enable miRNA binding [47] and probably other RNA species [61]. In EVs, sumoylated (SUMO = small ubiqiutin-related modifier) hnRNPA2B1 controls miRNA-binding and may also trigger the sorting [47]. An analog mechanism was reported for the RNA-binding protein Synaptotagmin Binding Cytoplasmic RNA Interacting Protein (SYNCRIP) in hepatocytes [48], which interacts with an EXO-motif and is also sumoylated. SYNCRIP is involved in several processing steps of mRNA and SYNCRIP deficiency reduced the miRNA content in MVB-derived EVs.

Microtubule-associated protein 1 light chain $3 \beta$ (Lc3b), an autophagy marker, was also detected within EVs. These EVs were described to arise from the fusion of MVBs with histone and dsDNA carrying autophagosomes. Recently, it was demonstrated that Lc3b and the conjugated machinery bind RNA binding proteins, like heterogenous nuclear ribonucleoprotein K (HNRNPK) and scaffold attachment factor B (SAFB), which then regulate the small non-coding RNA cargo within EVs [53].

\subsection{Transfer of Mitochondrial DNA}

While the vesicle transfer of RNAs has been long known, recent work identified a transfer of mitochondrial DNA (mtDNA) by EVs; the whole mitochondrial genome was isolated from blood circulating EVs from breast cancer patients [54]. This horizontal transfer of mtDNA was identified as a tool of cancer cells to augment the metabolic activity of recipient cells. Primarily, this mechanism was discovered in the context of hormonal therapy. Breast cancer cells sustain a dormancy stage after blockage of their oxidative phosphorylation. However, this process was inhibited by the mtDNA transfer of hormonal therapy-resistant cells, followed by metabolic recovery of recipient cells and metastatic progression [54]. Even the loading of complete mitochondria within EVs was reported [85]. Occurring in mesenchymal stem cells for instance, it might be a cellular mechanism to remove depolarized mitochondria and overcome oxidative stress. Mitochondria are relocated to the plasma membrane, where they are shed within EVs containing both ARRDC1 and TSG101. These mitochondria can be taken up by macrophages and have displayed an augmenting effect on the metabolism of these cells [86]. However, this study could not completely exclude the contamination of apoptotic bodies. Recently, Jeppesen et al. demonstrated that double-stranded DNA in general is rather associated with non-vesicular release (exomeres) than with EVs [22]. 


\subsection{Foreign Molecules}

Besides the variety of endogenous molecules detected within EVs, foreign molecules can also undergo cargo sorting. This can be a protective mechanism, for example in case of MHC-II bound antigens, which can trigger an immune response. Many viruses manipulate the endocytic pathway and utilize EV release to infect other cells. EVs and viruses often overlap in size ranges, which complicates investigation of viral molecules within EVs [4]. However, the hypothesis that EVs can be infectious was proven by Longatti et al., who demonstrated that subgenomic replicon cells lacking the production of virion structural proteins, were able to infect Huh7 cells [87]. The full genomic RNA of the Hepatitis $C$ virus was packed into EVs and transferred to a recipient cell. This mechanism was also described for Hepatitis A virus [88]. The loading of genomic RNA is only one example of viral components found in EVs. Furthermore, EVs can harbor viral miRNA [89] and non-coding RNA (Epstein-Barr Virus (EBV)) [90], as well as several proteins, like the latent membrane protein 1 (EBV) [91] or glycoprotein B (herpes simplex virus) [92]. A full list was compiled in the review of Khan et al. [93]. For retroviruses, a trojan exosome hypothesis was published in 2003 and describes how these viruses use the endogenous exosome mechanism of the host cell to form infectious, but mimicked particles [94]. For the human immunodeficiency virus (HIV), it is known that the protein negative regulatory factor (Nef) which is encoded in the lentiviral genome, increases EV release to promote infectivity $[95,96]$. In addition, Nef is loaded into EVs to improve HIV progression in surrounding cells [97]. It was reported that after infection and reproduction within the cell, HIV predominately bud from the cell membrane [98], which basically makes them microparticles. If, or at which point the virus leaves the endolysosomal system is virus type-dependent. Hepatitis $C$ and A virus use this pathway from clathrin-dependent endocytosis to fuse with late endosomes and finally, propagation via EVs [99]. Other viruses interact only with some EV components, like HIV with the ESCRT-machinery [100]. Influenza A virus interacts with members of the Rab family to facilitate transport to, and fusion with, the plasma membrane [101]. With regard to the severe acute respiratory syndrome coronavirus 2 (SARS-CoV 2) which causes coronavirus disease 2019 (COVID-19), no connection to the EV release pathway has been published thus far. Rather, clinical trials are being performed to examine the beneficial effect of mesenchymal stromal/stem cell (MSC)-derived EVs on COVID-19 disease (ChiCTR2000030484; NCT04276987). MSC-derived EVs are reported to have a therapeutic effect in a broad spectrum of diseases. Beneficial effects in ischemia-reperfusion induced kidney injury [102] and protective properties against myocardial infarction [103]; just two of many examples demonstrating their therapeutic potential. These EVs contain a specific enriched subset of miRNAs [104] and proteins [105], modulating cellular response and triggering tissue repair [106]. In the first attempt to treat patients suffering from SARS-CoV 2-induced acute respiratory distress syndrome, Sengupta et al. applied intravenously a single dose of $\mathrm{ExoFlo}^{\mathrm{TM}}$, an agent containing MSC-derived EVs to a small cohort of 27 patients and demonstrated restored oxygenation, reduced cytokine storm and reconstitute immunity [107]. These data are under debate from leading scientists in the field [108]. Apart from the non-randomization, non-blinding and small sample size, the transparency of the ExoFlo ${ }^{\mathrm{TM}}$ product is missing, with the authors providing only a limited amount of information about the origin, composition and characterization of ExoFlo ${ }^{\mathrm{TM}}[108]$.

\subsection{Mineral Crystals as Cargo of Calcifying EVs}

In the cardiovascular (CV) field, EVs have become a central point of interest due to a broad spectrum of systemic, but also pathological effects. They are well suited as biomarkers for several cardiovascular diseases; a detailed biomarker cargo list was compiled by Chong et al. [109]. By way of example, EVs have been shown as proinflammatory mediators after myocardial infarction by triggering cytokine release [110]. A subsequent promotion of angiogenesis in the damaged tissue was also reported [111].

More recently, EVs were identified as calcification initiators in ectopic calcification [11]. Calcifying EVs are released by aberrant macrophages or vascular smooth muscle cells (VSMCs) undergoing osteogenic transformation [112]. Calcifying EVs are of 30-100 $\mathrm{nm}$ size [113] and differ in density [114] 
since they can harbor amorphous calcium phosphate mineral [11], as well as hydroxyapatite [56]. Calcifying VSMCs release EVs prone to calcify and with an altered proteome [114], including an increase of collagen binding proteins like annexins or the tissue non-specific alkaline phosphatase (TNAP), which are linked to calcification (Figure 1) [115].

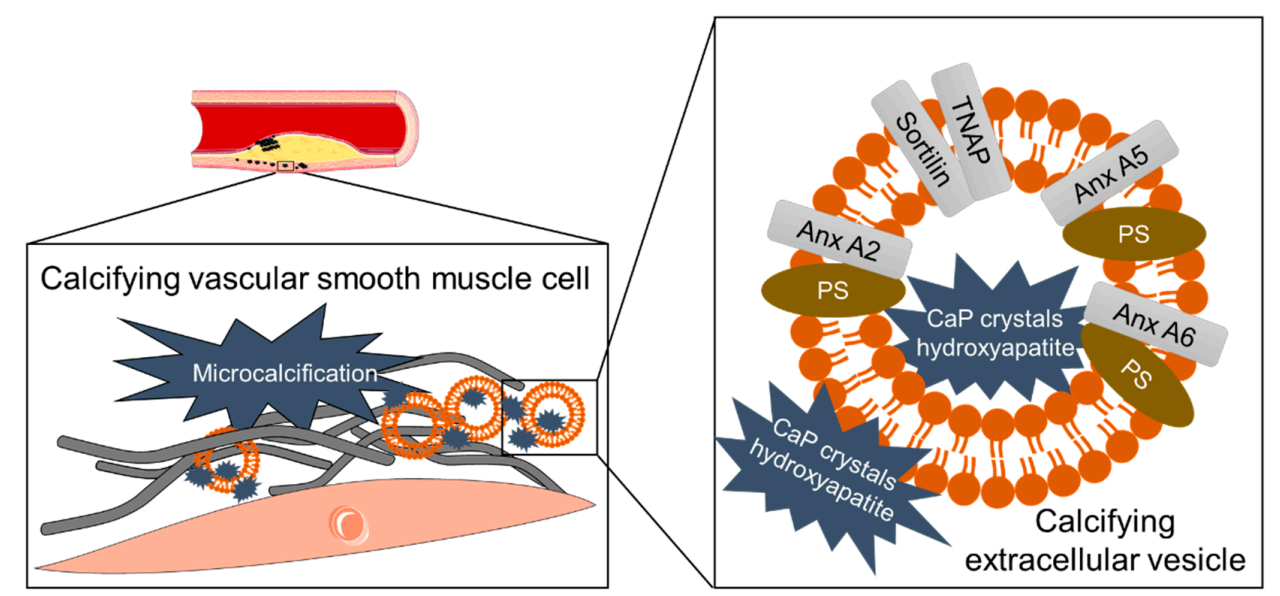

Figure 1. Calcifying extracellular vescilces trigger vascular microcalcification. Microcalcifications are formed within the vessel wall, triggered by released calcifying extracellular vesicles (EVs). These calcifying EVs have a characteristic proteomic and lipid composition. They can be carrier of calcium/phosphate crystals or hydroxyapatite. Anx: Annexin, CaP: Calciumphosphate, PS: Phosphatidylserine; TNAP: Tissue non-specific alkaline phosphatase.

The multiligand sorting receptor sortilin was identified to be crucial for TNAP loading into the calcifying EV membrane [116], which is enriched in phosphatidylserine, with a high affinity to calcium-ions [117]. Annexin A2 is another driver of mineralization, due to its activating effect on TNAP, as well as a reduction of Fetuin-A loading into EVs [118]. In high phosphate conditions also TNAP-negative EVs can nucleate mineralization [119]. This process is linked to an enriched intracellular calcium and simulates chronic kidney disease. The calcification of VSMCs can be blocked by inhibition of the n-SMase 2 that causes a reduction of endosome-derived EVs [55]. Recent studies demonstrated that Imipramine, an acid sphingomyelinase inhibitor, reduces the release of calcifying EVs in bone osteoblasts [120].

\section{Phosphoinositides Determine the Fate of Intraluminal Vesicles}

To identify single cellular components involved in EV formation or cargo loading, it is necessary to fully understand the molecular mechanism behind EV synthesis. Here, it is important to mention that EV formation is not an isolated, independent process; rather, dependent on a well-adjusted balance within the endolysosomal system. EV secretion and autophagy are those cellular processes which maintain cellular homeostasis and both pathways are closely linked. This connection is striking in neurodegenerative disease, where neuronal loss of autophagy causes accumulation of proteins within the cell [121]. The cell then dispose these proteins by enhanced EV release [122], leading to even further propagation [123]. To underline this association, a dysfunction of the EV cargo loading ESCRT-machinery causes autophagosomal accumulation, in turn leading to neurodegeneration [124].

As constantly processing intracellular compartments, endosomes and autophagosomes, as well as lysosomes, have much in common. Autophagy related proteins (ATGs) are described as taking part in EV formation and release. In the endolysosomal system, the recruitment of membrane proteins is determined by the composition of the compartment membrane, with a central role of phosphoinositides (PIs). The minor presence of PIs (about 10\% of phospholipids in eukaryotic cells [125]) belies a major impact on intracellular processes. Their frequency characterizes different compartments, as well as the endolysosomal maturation state (Figure 2). 


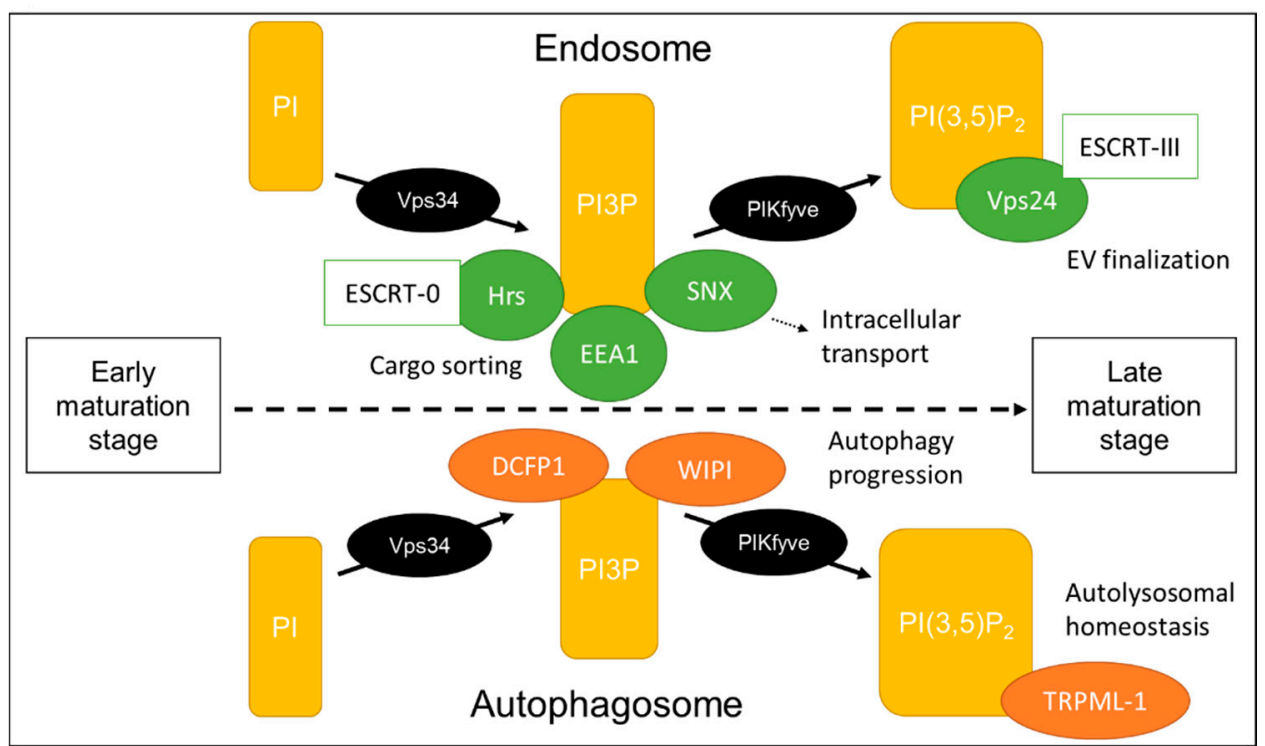

Figure 2. Phosphoinositides conversion defining endolysosomal maturation stage. The conversion of PIs within the endolysosomal compartment membrane allows for the effectors to bind and progress maturation. Although endosomes and autophagosomes share the same central phosphoinositide (PI) conversion, they both have specific effectors important for their specific function. DCFP1: Double FYVE domain-containing protein 1, EEA1: Early endosomal antigen 1, ESCRT: Endosomal sorting complex responsible for transport, Hrs: hepatocyte growth factor-regulated tyrosine kinase substrate, PI: Phosphoinositides, PIKfyve: Phosphatidylinositol-3-phosphate 5-kinase, SNX: Sorting nexin proteins, TRPML-1: Transient receptor potential cation channel 1, Vps: Vacuolar protein sorting, WIPI: WD-repeat protein interacting with PIs.

Furthermore, PIs are involved in vesicular transport by binding cytoskeletal proteins [126]. PIs are the phosphorylated form of phosphatidylinositol and characterized by an inositol ring, which can be phosphorylated at three different positions (D3, D4, D5). Several phosphatases and kinases are responsible for generating adequate levels of seven possible forms of PI. The most abundant PI is PI4P [127], which is a compartment of the Golgi membrane and involved in trafficking processes [128]. PI3P is less abundant and synthesized by PI3-kinase Vps34. It is enriched in the endolysosomal membranes and recruits other enzymes that are involved in either endosomal trafficking or autophagy [129]. In yeast, unfunctional Vps34 with aberrant PI3P synthesis affected protein sorting and at the same time dysregulated autophagosome formation [130]. The ESCRT-0 associated protein Hrs and the early endosomal antigen 1 (EEA1), both interact with PI3P at the endosomal membrane by their FYVE domain [131], thereby contributing to generation and protein sorting into MVBs. In addition, sorting nexin proteins (SNX) interact with PI3P and enable transport to the trans-Golgi and the plasma membrane [132]. At the autophagosomal membrane, Vps34-complex recruits double FYVE domain-containing protein 1 (DCFP1) and WD-repeat protein interacting with PIs (WIPI), which then trigger autophagy progression. PI3P is converted to $\mathrm{PI}(3,5) \mathrm{P}_{2}$ or PI5P by phosphatidylinositol-3-phosphate 5-kinase (PIKfyve), a known target to alter EV secretion. PI5P is described as a negative regulator of endosomal maturation and shown to influence protein internalization [133]. $\mathrm{PI}(3,5) \mathrm{P}_{2}$ is highly expressed on late endosomes, mature autophagosomes and at the lysosomal membrane. Its synthesis is crucial for autophagy progression, since mutations in PIKfyve cause accumulation of autophagosomal marker [134]. Transient receptor potential cation channel 1 (TRPML-1) is another downstream effector of $\mathrm{PI}(3,5) \mathrm{P}_{2}$ and a regulator of lysosomal size [135]. $\mathrm{PI}(3,5) \mathrm{P}_{2}$ removes cortactin from actin filaments, thereby regulating compartment movement [136]. It also has an important role in late endosomal protein sorting by binding to Vps24, a component of the ESCRT-III complex [137]. 
Taken together, PIs are fine-tune regulators in the cell and their proportion within the membranes is crucial to defining intracellular compartment identity and maturation stage. One of their diverse functions is the initiation of ILV regulation and cargo loading. They regulate extracellular secretion as well as recycling processes via autophagy, underlining the close connection between these two mechanisms. More and more, PIs are revealing to be an adequate target to influence EV composition and secretion.

\section{Inhibition and Promotion of EV Release for Therapeutic Approaches}

Successful alterations in EV release can be beneficial in preventing the progression of diverse diseases. For example, in a sepsis mouse model the blockage of ceramide synthesis and subsequent inhibition of EV release, demonstrated a reduction of inflammation and an improved survival rate [138]. The inhibition of EV release in the central nervous system may prevent prion expansion [139] in neurodegenerative diseases. Therefore, EVs offer promising tools for novel treatment strategies. Recent publications demonstrate the successful utilization of EVs as drug-carrying transporters [140,141], to overcome multiple drug resistance in cancer [142] or Parkinson's [143] disease therapy. In addition, EVs can be loaded with siRNAs, which are efficiently uptaken by recipient cells [144]. Another way to therapeutically load EVs is to intervene in EV biogenesis. One method involves labelling targeted proteins with WW-tag, leading to loading into EVs by Ndfip1 [40]. Of late, efforts have been made to construct EV-mimics for successful drug delivery (reviewed in [46]). An overview of the usage of EVs as therapeutic vehicles was recently reviewed by Melling et al. [145].

Besides silencing of proteins involved in EV formation, several compounds were discovered to block or augment EV release (Figure 3).

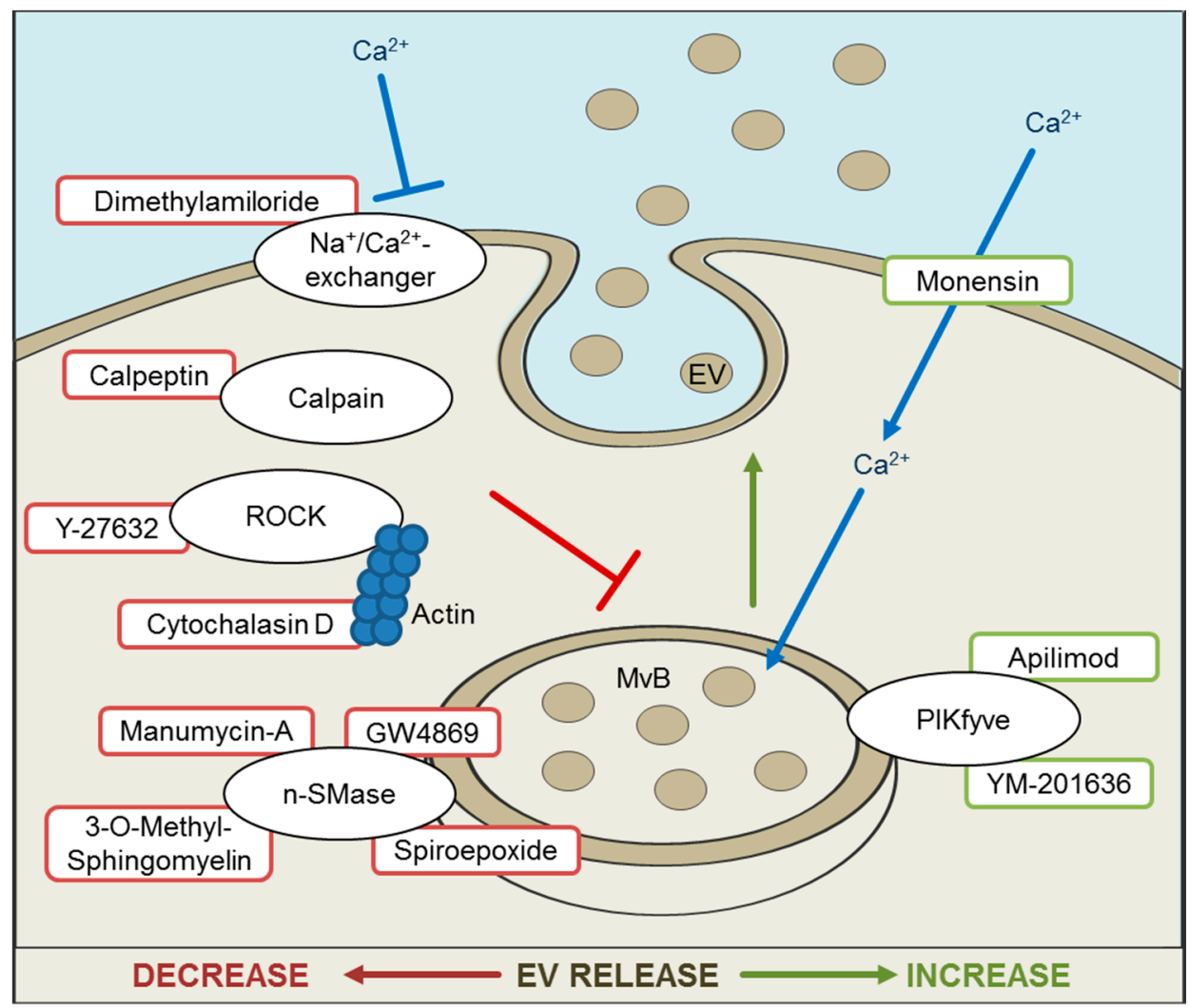

Figure 3. Inhibition and promotion of extracellular vesicle (EV) release. Overview of substances and their targets with enhancing (right side) or inhibitory (left side) effect on EV release. n-SMase: Sphingomyelinase, PIKfyve: Phosphatidylinositol-3-phosphate 5-kinase, ROCK: Rho-associated, coiled-coil containing protein kinase, MvB: multivesicular body. 
One general mechanism of reducing EV release is the interruption of intercellular $\mathrm{Ca}^{2+}$ by calcium-chelators. Ionophore monensin is a membrane permeable $\mathrm{H}^{+} / \mathrm{Na}^{+}$-antiporter, which elevates the quantity of intracellular $\mathrm{Ca}^{2+}$ [146] and thereby enhances exosomal secretion [147]. $\mathrm{Ca}^{2+}$ accumulates within MVBs and causes water influx, leading to extended MVBs. A monesin-like effect has been attributed to Cortactin overexpression. Cortactin is an actin-nucleation factor, involved in endocytosis, cell migration and MVB trafficking [136], and increases MVB-derived EV release. Unlike cortactin overexpression, monesin induces reactive oxygen species (ROS) formation and oxidative stress, prompting apoptosis and changes in EV composition [148]. Further analysis is necessary to examine the effect on alterations of EV cargo. Dimethylamiloride (DMA) blocks $\mathrm{H}^{+} / \mathrm{Na}^{+}$and $\mathrm{Na}^{+} / \mathrm{Ca}^{2+}$-exchange, suppresses MVB swelling and therefore vesicle release [147].

The inhibition of the n-SMase2, via siRNA or pharmacological agents, demonstrated an EV release reduction. GW4869 is a non-competitive inhibitor of the n-SMase 2 and blocks ceramide synthesis, which then suppresses inward budding of MVBs, resulting in a reduction of EV formation. GW4869 was first tested in HEK293 cells [84], but is a prominent tool for inhibiting EV release [138,149]. Other examples for n-SMase inhibitors are 3-O-Methyl-sphingomyelin and Spiroepoxide [55]. The antibiotic Manumycin A is mainly described as a competitive inhibitor of the Ras farnesyltransferase, but is also an irreversible inhibitor of the n-SMase [150]. Both targets are involved in EV synthesis [151], and an inhibition leads to EV release reduction. Yet, the blockage of n-SMase does not inhibit EV release in all cell types, as demonstrated in the prostate cancer cell line PC-3 [152]. It has been suggested that the role of ceramide is cell type-dependent, which could be in line with observed differences in subcellular localization of the n-SMase [152,153]. Tricyclic anti-depressant Imipramine is an inhibitor of acid sphingomyelinase and has demonstrated a reduction of EVs derived from osteoblasts [120].

Another method of inhibiting EV release is to hinder intracellular transport by targeting structural components. Cytochalasin D is a cell permeable mycotoxin which inhibits actin-polymerization and decreases EV release [154]. Y-27632 inhibits Rho-associated, coiled-coil containing protein kinase (ROCK) 1 and 2 by competing with ATP. ROCK contributes to actin formation and membrane deformation. Calpeptin is an inhibitor of calpain, $\mathrm{a} \mathrm{Ca}^{2+}$-dependent protease involved in many cellular processes [155]. Y-27632, as well as Calpeptin, prevents the formation of EVs budding directly from the cell membrane [156].

The inhibition of lipid kinase PIKfyve demonstrated enhanced EV secretion in a prostate cancer cell line [157]. Apilimod (STA-5326) and YM201636 are known PIKfyve inhibitors. PIKfyve phosphorylates PI3P which is abundant in endolysosomal membranes and the conversion causes MVB maturation.

\section{Conclusions}

Scientific interest in EVs has grown enormously over recent decades, across nearly every biological research field. Not least, the global COVID-19 pandemic demonstrates that besides being possible vehicles for disease spreading, EVs represent a good chance to counter disease. Pooling differently termed vesicles into one big heterogeneous EV group made it possible to combine the knowledge of several separate observations. On the other hand, uncertainty remains as to how to characterize EVs with clearly differing release mechanisms. Furthermore, we need an illumination of the cellular pathways involved in formation, cargo loading, release, and uptake, of which we only have partial knowledge. Here, we provide an overview of observed intracellular structures that are possibly closely linked. We list established strategies to alter EV release, with or without influencing EV cargo. However, when utilizing these effectors, it is necessary to bear in mind the close crosslinking of intracellular processes. By influencing EV release, the autophagy and-in all likelihood—several other cellular processes will also be altered. Inversely, alterations in intracellular membrane composition or autophagy may be a tool to influence secreted EVs too, and thereby, positively affect disease progression. 
Author Contributions: Conceptualization, B.M. and C.G.; formal analysis (literature search), B.M.; writingoriginal draft preparation, B.M.; writing-review and editing, C.G.; visualization, B.M.; supervision, C.G.; project administration, C.G.; funding acquisition, C.G. All authors have read and agreed to the published version of the manuscript.

Funding: Claudia Goettsch is supported by the START-Program of the Faculty of Medicine, RWTH Aachen and German Research Foundation grant GO1801/5-1 and SBF-TRR219-C02.

Conflicts of Interest: The authors declare no conflict of interest.

\section{References}

1. McGough, I.J.; Vincent, J.P. Exosomes in developmental signalling. Development 2016, 143, $2482-2493$. [CrossRef]

2. Buschow, S.I.; Nolte-'t Hoen, E.N.; van Niel, G.; Pols, M.S.; ten Broeke, T.; Lauwen, M.; Ossendorp, F.; Melief, C.J.; Raposo, G.; Wubbolts, R.; et al. MHC II in dendritic cells is targeted to lysosomes or T cell-induced exosomes via distinct multivesicular body pathways. Traffic 2009, 10, 1528-1542. [CrossRef] [PubMed]

3. Thery, C.; Regnault, A.; Garin, J.; Wolfers, J.; Zitvogel, L.; Ricciardi-Castagnoli, P.; Raposo, G.; Amigorena, S. Molecular characterization of dendritic cell-derived exosomes. Selective accumulation of the heat shock protein hsc73. J. Cell. Biol. 1999, 147, 599-610. [CrossRef] [PubMed]

4. Anderson, M.R.; Kashanchi, F.; Jacobson, S. Exosomes in Viral Disease. Neurotherapeutics 2016, 13, 535-546. [CrossRef]

5. Zhou, X.; Zhang, W.; Yao, Q.; Zhang, H.; Dong, G.; Zhang, M.; Liu, Y.; Chen, J.K.; Dong, Z. Exosome production and its regulation of EGFR during wound healing in renal tubular cells. Am. J. Physiol. Renal Physiol. 2017, 312, F963-F970. [CrossRef]

6. Zhang, H.; Deng, T.; Liu, R.; Bai, M.; Zhou, L.; Wang, X.; Li, S.; Wang, X.; Yang, H.; Li, J.; et al. Exosomedelivered EGFR regulates liver microenvironment to promote gastric cancer liver metastasis. Nat. Commun. 2017, 8, 15016. [CrossRef]

7. Abd Elmageed, Z.Y.; Yang, Y.; Thomas, R.; Ranjan, M.; Mondal, D.; Moroz, K.; Fang, Z.; Rezk, B.M.; Moparty, K.; Sikka, S.C.; et al. Neoplastic reprogramming of patient-derived adipose stem cells by prostate cancer cell-associated exosomes. Stem Cells 2014, 32, 983-997. [CrossRef] [PubMed]

8. Coleman, B.M.; Hill, A.F. Extracellular vesicles-Their role in the packaging and spread of misfolded proteins associated with neurodegenerative diseases. Semin. Cell. Dev. Biol. 2015, 40, 89-96. [CrossRef] [PubMed]

9. Fruhbeis, C.; Frohlich, D.; Kuo, W.P.; Kramer-Albers, E.M. Extracellular vesicles as mediators of neuron-glia communication. Front. Cell. Neurosci. 2013, 7, 182. [CrossRef]

10. Cappariello, A.; Loftus, A.; Muraca, M.; Maurizi, A.; Rucci, N.; Teti, A. Osteoblast-Derived Extracellular Vesicles Are Biological Tools for the Delivery of Active Molecules to Bone. J. Bone Miner. Res. 2018, 33, 517-533. [CrossRef]

11. Hutcheson, J.D.; Goettsch, C.; Bertazzo, S.; Maldonado, N.; Ruiz, J.L.; Goh, W.; Yabusaki, K.; Faits, T.; Bouten, C.; Franck, G.; et al. Genesis and growth of extracellular-vesicle-derived microcalcification in atherosclerotic plaques. Nat. Mater. 2016, 15, 335-343. [CrossRef]

12. van der Pol, E.; Boing, A.N.; Gool, E.L.; Nieuwland, R. Recent developments in the nomenclature, presence, isolation, detection and clinical impact of extracellular vesicles. J. Thromb. Haemost. 2016, 14, 48-56. [CrossRef]

13. Araldi, E.; Kramer-Albers, E.M.; Hoen, E.N.; Peinado, H.; Psonka-Antonczyk, K.M.; Rao, P.; van Niel, G.; Yanez-Mo, M.; Nazarenko, I. International Society for Extracellular Vesicles: First annual meeting, April 17-21, 2012: ISEV-2012. J. Extracell. Vesicles 2012, 1, 19995. [CrossRef]

14. Thery, C.; Witwer, K.W.; Aikawa, E.; Alcaraz, M.J.; Anderson, J.D.; Andriantsitohaina, R.; Antoniou, A.; Arab, T.; Archer, F.; Atkin-Smith, G.K.; et al. Minimal information for studies of extracellular vesicles 2018 (MISEV2018): A position statement of the International Society for Extracellular Vesicles and update of the MISEV2014 guidelines. J. Extracell. Vesicles 2018, 7, 1535750. [CrossRef]

15. Athman, J.J.; Wang, Y.; McDonald, D.J.; Boom, W.H.; Harding, C.V.; Wearsch, P.A. Bacterial Membrane Vesicles Mediate the Release of Mycobacterium tuberculosis Lipoglycans and Lipoproteins from Infected Macrophages. J. Immunol. 2015, 195, 1044-1053. [CrossRef] 
16. Kowal, J.; Arras, G.; Colombo, M.; Jouve, M.; Morath, J.P.; Primdal-Bengtson, B.; Dingli, F.; Loew, D.; Tkach, M.; Thery, C. Proteomic comparison defines novel markers to characterize heterogeneous populations of extracellular vesicle subtypes. Proc. Natl. Acad. Sci. USA 2016, 113, E968-E977. [CrossRef]

17. Zhang, H.; Freitas, D.; Kim, H.S.; Fabijanic, K.; Li, Z.; Chen, H.; Mark, M.T.; Molina, H.; Martin, A.B.; Bojmar, L.; et al. Identification of distinct nanoparticles and subsets of extracellular vesicles by asymmetric flow field-flow fractionation. Nat. Cell. Biol. 2018, 20, 332-343. [CrossRef]

18. Zhang, Q.; Higginbotham, J.N.; Jeppesen, D.K.; Yang, Y.P.; Li, W.; McKinley, E.T.; Graves-Deal, R.; Ping, J.; Britain, C.M.; Dorsett, K.A.; et al. Transfer of Functional Cargo in Exomeres. Cell Rep. 2019, 27, 940-954.e946. [CrossRef]

19. Larson, M.C.; Woodliff, J.E.; Hillery, C.A.; Kearl, T.J.; Zhao, M. Phosphatidylethanolamine is externalized at the surface of microparticles. Biochim. Biophys. Acta 2012, 1821, 1501-1507. [CrossRef]

20. Cosenza, S.; Toupet, K.; Maumus, M.; Luz-Crawford, P.; Blanc-Brude, O.; Jorgensen, C.; Noel, D. Mesenchymal stem cells-derived exosomes are more immunosuppressive than microparticles in inflammatory arthritis. Theranostics 2018, 8, 1399-1410. [CrossRef] [PubMed]

21. Brites, D.; Fernandes, A. Neuroinflammation and Depression: Microglia Activation, Extracellular Microvesicles and microRNA Dysregulation. Front. Cell. Neurosci. 2015, 9, 476. [CrossRef] [PubMed]

22. Jeppesen, D.K.; Fenix, A.M.; Franklin, J.L.; Higginbotham, J.N.; Zhang, Q.; Zimmerman, L.J.; Liebler, D.C.; Ping, J.; Liu, Q.; Evans, R.; et al. Reassessment of Exosome Composition. Cell 2019, 177, $428-445$ e418. [CrossRef] [PubMed]

23. Piccin, A.; Murphy, W.G.; Smith, O.P. Circulating microparticles: Pathophysiology and clinical implications. Blood Rev. 2007, 21, 157-171. [CrossRef]

24. Atkin-Smith, G.K.; Tixeira, R.; Paone, S.; Mathivanan, S.; Collins, C.; Liem, M.; Goodall, K.J.; Ravichandran, K.S.; Hulett, M.D.; Poon, I.K. A novel mechanism of generating extracellular vesicles during apoptosis via a beads-on-a-string membrane structure. Nat. Commun. 2015, 6, 7439. [CrossRef]

25. Atkin-Smith, G.K.; Paone, S.; Zanker, D.J.; Duan, M.; Phan, T.K.; Chen, W.; Hulett, M.D.; Poon, I.K. Isolation of cell type-specific apoptotic bodies by fluorescence-activated cell sorting. Sci. Rep. 2017, 7, 39846. [CrossRef]

26. Huang, P.H.; Huang, S.S.; Chen, Y.H.; Lin, C.P.; Chiang, K.H.; Chen, J.S.; Tsai, H.Y.; Lin, F.Y.; Chen, J.W.; Lin, S.J. Increased circulating CD31+/annexin $\mathrm{V}+$ apoptotic microparticles and decreased circulating endothelial progenitor cell levels in hypertensive patients with microalbuminuria. J. Hypertens. 2010, 28, 1655-1665. [CrossRef]

27. Osteikoetxea, X.; Nemeth, A.; Sodar, B.W.; Vukman, K.V.; Buzas, E.I. Extracellular vesicles in cardiovascular disease: Are they Jedi or Sith? J. Physiol. 2016, 594, 2881-2894. [CrossRef]

28. Boing, A.N.; van der Pol, E.; Grootemaat, A.E.; Coumans, F.A.; Sturk, A.; Nieuwland, R. Single-step isolation of extracellular vesicles by size-exclusion chromatography. J. Extracell. Vesicles 2014, 3. [CrossRef]

29. Wang, W.; Luo, J.; Wang, S. Recent Progress in Isolation and Detection of Extracellular Vesicles for Cancer Diagnostics. Adv. Healthc. Mater 2018, 7, e1800484. [CrossRef]

30. Wiklander, O.P.B.; Bostancioglu, R.B.; Welsh, J.A.; Zickler, A.M.; Murke, F.; Corso, G.; Felldin, U.; Hagey, D.W.; Evertsson, B.; Liang, X.M.; et al. Systematic Methodological Evaluation of a Multiplex Bead-Based Flow Cytometry Assay for Detection of Extracellular Vesicle Surface Signatures. Front. Immunol. 2018, 9, 1326. [CrossRef]

31. Campos-Silva, C.; Suarez, H.; Jara-Acevedo, R.; Linares-Espinos, E.; Martinez-Pineiro, L.; Yanez-Mo, M.; Vales-Gomez, M. High sensitivity detection of extracellular vesicles immune-captured from urine by conventional flow cytometry. Sci. Rep. 2019, 9, 2042. [CrossRef] [PubMed]

32. Pospichalova, V.; Svoboda, J.; Dave, Z.; Kotrbova, A.; Kaiser, K.; Klemova, D.; Ilkovics, L.; Hampl, A.; Crha, I.; Jandakova, E.; et al. Simplified protocol for flow cytometry analysis of fluorescently labeled exosomes and microvesicles using dedicated flow cytometer. J. Extracell. Vesicles 2015, 4, 25530. [CrossRef] [PubMed]

33. Gidlof, O.; Evander, M.; Rezeli, M.; Marko-Varga, G.; Laurell, T.; Erlinge, D. Proteomic profiling of extracellular vesicles reveals additional diagnostic biomarkers for myocardial infarction compared to plasma alone. Sci. Rep. 2019, 9, 8991. [CrossRef]

34. Katzmann, D.J.; Babst, M.; Emr, S.D. Ubiquitin-dependent sorting into the multivesicular body pathway requires the function of a conserved endosomal protein sorting complex, ESCRT-I. Cell 2001, 106, 145-155. [CrossRef] 
35. Villarroya-Beltri, C.; Baixauli, F.; Mittelbrunn, M.; Fernandez-Delgado, I.; Torralba, D.; Moreno-Gonzalo, O.; Baldanta, S.; Enrich, C.; Guerra, S.; Sanchez-Madrid, F. ISGylation controls exosome secretion by promoting lysosomal degradation of MVB proteins. Nat. Commun. 2016, 7, 13588. [CrossRef]

36. Ageta, H.; Ageta-Ishihara, N.; Hitachi, K.; Karayel, O.; Onouchi, T.; Yamaguchi, H.; Kahyo, T.; Hatanaka, K.; Ikegami, K.; Yoshioka, Y.; et al. UBL3 modification influences protein sorting to small extracellular vesicles. Nat. Commun. 2018, 9, 3936. [CrossRef]

37. Dores, M.R.; Chen, B.; Lin, H.; Soh, U.J.; Paing, M.M.; Montagne, W.A.; Meerloo, T.; Trejo, J. ALIX binds a YPX(3)L motif of the GPCR PAR1 and mediates ubiquitin-independent ESCRT-III/MVB sorting. J. Cell. Biol. 2012, 197, 407-419. [CrossRef]

38. Roucourt, B.; Meeussen, S.; Bao, J.; Zimmermann, P.; David, G. Heparanase activates the syndecansyntenin-ALIX exosome pathway. Cell. Res. 2015, 25, 412-428. [CrossRef]

39. Putz, U.; Howitt, J.; Lackovic, J.; Foot, N.; Kumar, S.; Silke, J.; Tan, S.S. Nedd4 family-interacting protein 1 (Ndfip1) is required for the exosomal secretion of Nedd4 family proteins. J. Biol. Chem. 2008, 283, 32621-32627. [CrossRef]

40. Sterzenbach, U.; Putz, U.; Low, L.H.; Silke, J.; Tan, S.S.; Howitt, J. Engineered Exosomes as Vehicles for Biologically Active Proteins. Mol. Ther. 2017, 25, 1269-1278. [CrossRef]

41. Kajimoto, T.; Okada, T.; Miya, S.; Zhang, L.; Nakamura, S. Ongoing activation of sphingosine 1-phosphate receptors mediates maturation of exosomal multivesicular endosomes. Nat. Commun. 2013, 4, 2712. [CrossRef] [PubMed]

42. Mazurov, D.; Barbashova, L.; Filatov, A. Tetraspanin protein CD9 interacts with metalloprotease CD10 and enhances its release via exosomes. FEBS J. 2013, 280, 1200-1213. [CrossRef]

43. van Niel, G.; Charrin, S.; Simoes, S.; Romao, M.; Rochin, L.; Saftig, P.; Marks, M.S.; Rubinstein, E.; Raposo, G. The tetraspanin CD63 regulates ESCRT-independent and -dependent endosomal sorting during melanogenesis. Dev. Cell. 2011, 21, 708-721. [CrossRef]

44. Nabhan, J.F.; Hu, R.; Oh, R.S.; Cohen, S.N.; Lu, Q. Formation and release of arrestin domain-containing protein 1-mediated microvesicles (ARMMs) at plasma membrane by recruitment of TSG101 protein. Proc. Natl. Acad. Sci. USA 2012, 109, 4146-4151. [CrossRef] [PubMed]

45. Gangalum, R.K.; Atanasov, I.C.; Zhou, Z.H.; Bhat, S.P. AlphaB-crystallin is found in detergent-resistant membrane microdomains and is secreted via exosomes from human retinal pigment epithelial cells. J Biol. Chem. 2011, 286, 3261-3269. [CrossRef]

46. Li, S.P.; Lin, Z.X.; Jiang, X.Y.; Yu, X.Y. Exosomal cargo-loading and synthetic exosome-mimics as potential therapeutic tools. Acta Pharmacol. Sin. 2018, 39, 542-551. [CrossRef]

47. Villarroya-Beltri, C.; Gutierrez-Vazquez, C.; Sanchez-Cabo, F.; Perez-Hernandez, D.; Vazquez, J.; Martin-Cofreces, N.; Martinez-Herrera, D.J.; Pascual-Montano, A.; Mittelbrunn, M.; Sanchez-Madrid, F. Sumoylated hnRNPA2B1 controls the sorting of miRNAs into exosomes through binding to specific motifs. Nat. Commun. 2013, 4, 2980. [CrossRef] [PubMed]

48. Santangelo, L.; Giurato, G.; Cicchini, C.; Montaldo, C.; Mancone, C.; Tarallo, R.; Battistelli, C.; Alonzi, T.; Weisz, A.; Tripodi, M. The RNA-Binding Protein SYNCRIP Is a Component of the Hepatocyte Exosomal Machinery Controlling MicroRNA Sorting. Cell Rep. 2016, 17, 799-808. [CrossRef] [PubMed]

49. Iavello, A.; Frech, V.S.; Gai, C.; Deregibus, M.C.; Quesenberry, P.J.; Camussi, G. Role of Alix in miRNA packaging during extracellular vesicle biogenesis. Int. J. Mol. Med. 2016, 37, 958-966. [CrossRef]

50. Cha, D.J.; Franklin, J.L.; Dou, Y.; Liu, Q.; Higginbotham, J.N.; Demory Beckler, M.; Weaver, A.M.; Vickers, K.; Prasad, N.; Levy, S.; et al. KRAS-dependent sorting of miRNA to exosomes. Elife 2015, 4, e07197. [CrossRef]

51. Shurtleff, M.J.; Temoche-Diaz, M.M.; Karfilis, K.V.; Ri, S.; Schekman, R. Y-box protein 1 is required to sort microRNAs into exosomes in cells and in a cell-free reaction. Elife 2016, 5. [CrossRef] [PubMed]

52. Mukherjee, K.; Ghoshal, B.; Ghosh, S.; Chakrabarty, Y.; Shwetha, S.; Das, S.; Bhattacharyya, S.N. Reversible HuR-microRNA binding controls extracellular export of miR-122 and augments stress response. EMBO Rep. 2016, 17, 1184-1203. [CrossRef] [PubMed]

53. Leidal, A.M.; Huang, H.H.; Marsh, T.; Solvik, T.; Zhang, D.; Ye, J.; Kai, F.; Goldsmith, J.; Liu, J.Y.; Huang, Y.H.; et al. The LC3-conjugation machinery specifies the loading of RNA-binding proteins into extracellular vesicles. Nat. Cell. Biol. 2020, 22, 187-199. [CrossRef] 
54. Sansone, P.; Savini, C.; Kurelac, I.; Chang, Q.; Amato, L.B.; Strillacci, A.; Stepanova, A.; Iommarini, L.; Mastroleo, C.; Daly, L.; et al. Packaging and transfer of mitochondrial DNA via exosomes regulate escape from dormancy in hormonal therapy-resistant breast cancer. Proc. Natl. Acad. Sci. USA 2017, 114, E9066-E9075. [CrossRef] [PubMed]

55. Kapustin, A.N.; Chatrou, M.L.; Drozdov, I.; Zheng, Y.; Davidson, S.M.; Soong, D.; Furmanik, M.; Sanchis, P.; De Rosales, R.T.; Alvarez-Hernandez, D.; et al. Vascular smooth muscle cell calcification is mediated by regulated exosome secretion. Circ. Res. 2015, 116, 1312-1323. [CrossRef]

56. Wuthier, R.E.; Wu, L.N.; Sauer, G.R.; Genge, B.R.; Yoshimori, T.; Ishikawa, Y. Mechanism of matrix vesicle calcification: Characterization of ion channels and the nucleational core of growth plate vesicles. Bone Miner. 1992, 17, 290-295. [CrossRef]

57. Raposo, G.; Stoorvogel, W. Extracellular vesicles: Exosomes, microvesicles, and friends. J. Cell. Biol. 2013, 200, 373-383. [CrossRef]

58. Frankel, E.B.; Audhya, A. ESCRT-dependent cargo sorting at multivesicular endosomes. Semin. Cell Dev. Biol. 2018, 74, 4-10. [CrossRef]

59. Norris, A.; Tammineni, P.; Wang, S.; Gerdes, J.; Murr, A.; Kwan, K.Y.; Cai, Q.; Grant, B.D. SNX-1 and RME-8 oppose the assembly of HGRS-1/ESCRT-0 degradative microdomains on endosomes. Proc. Natl. Acad. Sci. USA 2017, 114, E307-E316. [CrossRef]

60. Gillooly, D.J.; Raiborg, C.; Stenmark, H. Phosphatidylinositol 3-phosphate is found in microdomains of early endosomes. Histochem. Cell. Biol. 2003, 120, 445-453. [CrossRef]

61. Villarroya-Beltri, C.; Baixauli, F.; Gutierrez-Vazquez, C.; Sanchez-Madrid, F.; Mittelbrunn, M. Sorting it out: Regulation of exosome loading. Semin. Cancer Biol. 2014, 28, 3-13. [CrossRef] [PubMed]

62. Boura, E.; Ivanov, V.; Carlson, L.A.; Mizuuchi, K.; Hurley, J.H. Endosomal sorting complex required for transport (ESCRT) complexes induce phase-separated microdomains in supported lipid bilayers. J. Biol. Chem. 2012, 287, 28144-28151. [CrossRef] [PubMed]

63. Teo, H.; Perisic, O.; Gonzalez, B.; Williams, R.L. ESCRT-II, an endosome-associated complex required for protein sorting: Crystal structure and interactions with ESCRT-III and membranes. Dev. Cell. 2004, 7, 559-569. [CrossRef] [PubMed]

64. Hurley, J.H.; Boura, E.; Carlson, L.A.; Rozycki, B. Membrane budding. Cell 2010, 143, 875-887. [CrossRef] [PubMed]

65. Agromayor, M.; Martin-Serrano, J. Interaction of AMSH with ESCRT-III and deubiquitination of endosomal cargo. J. Biol. Chem. 2006, 281, 23083-23091. [CrossRef]

66. Sun, S.; Zhou, X.; Zhang, W.; Gallick, G.E.; Kuang, J. Unravelling the pivotal role of Alix in MVB sorting and silencing of the activated EGFR. Biochem. J. 2015, 466, 475-487. [CrossRef]

67. Dores, M.R.; Grimsey, N.J.; Mendez, F.; Trejo, J. ALIX Regulates the Ubiquitin-Independent Lysosomal Sorting of the P2Y1 Purinergic Receptor via a YPX3L Motif. PLoS ONE 2016, 11, e0157587. [CrossRef]

68. Geminard, C.; De Gassart, A.; Blanc, L.; Vidal, M. Degradation of AP2 during reticulocyte maturation enhances binding of hsc70 and Alix to a common site on TFR for sorting into exosomes. Traffic 2004, 5, 181-193. [CrossRef]

69. Matsuo, H.; Chevallier, J.; Mayran, N.; Le Blanc, I.; Ferguson, C.; Faure, J.; Blanc, N.S.; Matile, S.; Dubochet, J.; Sadoul, R.; et al. Role of LBPA and Alix in multivesicular liposome formation and endosome organization. Science 2004, 303, 531-534. [CrossRef]

70. Baietti, M.F.; Zhang, Z.; Mortier, E.; Melchior, A.; Degeest, G.; Geeraerts, A.; Ivarsson, Y.; Depoortere, F.; Coomans, C.; Vermeiren, E.; et al. Syndecan-syntenin-ALIX regulates the biogenesis of exosomes. Nat. Cell. Biol. 2012, 14, 677-685. [CrossRef]

71. Friand, V.; David, G.; Zimmermann, P. Syntenin and syndecan in the biogenesis of exosomes. Biol. Cell 2015, 107, 331-341. [CrossRef]

72. Stuffers, S.; Sem Wegner, C.; Stenmark, H.; Brech, A. Multivesicular endosome biogenesis in the absence of ESCRTs. Traffic 2009, 10, 925-937. [CrossRef]

73. Edgar, J.R.; Eden, E.R.; Futter, C.E. Hrs- and CD63-dependent competing mechanisms make different sized endosomal intraluminal vesicles. Traffic 2014, 15, 197-211. [CrossRef]

74. Trajkovic, K.; Hsu, C.; Chiantia, S.; Rajendran, L.; Wenzel, D.; Wieland, F.; Schwille, P.; Brugger, B.; Simons, M. Ceramide triggers budding of exosome vesicles into multivesicular endosomes. Science 2008, 319, 1244-1247. [CrossRef] [PubMed] 
75. Mobius, W.; Ohno-Iwashita, Y.; van Donselaar, E.G.; Oorschot, V.M.; Shimada, Y.; Fujimoto, T.; Heijnen, H.F.; Geuze, H.J.; Slot, J.W. Immunoelectron microscopic localization of cholesterol using biotinylated and non-cytolytic perfringolysin O. J. Histochem. Cytochem. 2002, 50, 43-55. [CrossRef]

76. Harada, Y.; Suzuki, T.; Fukushige, T.; Kizuka, Y.; Yagi, H.; Yamamoto, M.; Kondo, K.; Inoue, H.; Kato, K.; Taniguchi, N.; et al. Generation of the heterogeneity of extracellular vesicles by membrane organization and sorting machineries. Biochim. Biophys. Acta 2019, 1863, 681-691. [CrossRef] [PubMed]

77. Ghossoub, R.; Lembo, F.; Rubio, A.; Gaillard, C.B.; Bouchet, J.; Vitale, N.; Slavik, J.; Machala, M.; Zimmermann, P. Syntenin-ALIX exosome biogenesis and budding into multivesicular bodies are controlled by ARF6 and PLD2. Nat. Commun. 2014, 5, 3477. [CrossRef] [PubMed]

78. Juan, T.; Fürthauer, M. Biogenesis and function of ESCRT-dependent extracellular vesicles. Semin. Cell. Dev. Biol. 2017, 74, 66-77. [CrossRef] [PubMed]

79. Koppers-Lalic, D.; Hackenberg, M.; Bijnsdorp, I.V.; van Eijndhoven, M.A.J.; Sadek, P.; Sie, D.; Zini, N.; Middeldorp, J.M.; Ylstra, B.; de Menezes, R.X.; et al. Nontemplated nucleotide additions distinguish the small RNA composition in cells from exosomes. Cell Rep. 2014, 8, 1649-1658. [CrossRef]

80. Nolte-'t Hoen, E.N.; Buermans, H.P.; Waasdorp, M.; Stoorvogel, W.; Wauben, M.H.; t Hoen, P.A. Deep sequencing of RNA from immune cell-derived vesicles uncovers the selective incorporation of small non-coding RNA biotypes with potential regulatory functions. Nucleic Acids Res. 2012, 40, 9272-9285. [CrossRef] [PubMed]

81. Mittelbrunn, M.; Gutierrez-Vazquez, C.; Villarroya-Beltri, C.; Gonzalez, S.; Sanchez-Cabo, F.; Gonzalez, M.A.; Bernad, A.; Sanchez-Madrid, F. Unidirectional transfer of microRNA-loaded exosomes from T cells to antigen-presenting cells. Nat. Commun. 2011, 2, 282. [CrossRef]

82. Tran, N. Cancer Exosomes as miRNA Factories. Trends Cancer 2016, 2, 329-331. [CrossRef] [PubMed]

83. Gibbings, D.J.; Ciaudo, C.; Erhardt, M.; Voinnet, O. Multivesicular bodies associate with components of miRNA effector complexes and modulate miRNA activity. Nat. Cell. Biol. 2009, 11, 1143-1149. [CrossRef] [PubMed]

84. Kosaka, N.; Iguchi, H.; Yoshioka, Y.; Takeshita, F.; Matsuki, Y.; Ochiya, T. Secretory mechanisms and intercellular transfer of microRNAs in living cells. J. Biol. Chem. 2010, 285, 17442-17452. [CrossRef]

85. Spees, J.L.; Olson, S.D.; Whitney, M.J.; Prockop, D.J. Mitochondrial transfer between cells can rescue aerobic respiration. Proc. Natl. Acad. Sci. USA 2006, 103, 1283-1288. [CrossRef] [PubMed]

86. Phinney, D.G.; Di Giuseppe, M.; Njah, J.; Sala, E.; Shiva, S.; St Croix, C.M.; Stolz, D.B.; Watkins, S.C.; Di, Y.P.; Leikauf, G.D.; et al. Mesenchymal stem cells use extracellular vesicles to outsource mitophagy and shuttle microRNAs. Nat. Commun. 2015, 6, 8472. [CrossRef] [PubMed]

87. Longatti, A.; Boyd, B.; Chisari, F.V. Virion-independent transfer of replication-competent hepatitis C virus RNA between permissive cells. J. Virol. 2015, 89, 2956-2961. [CrossRef] [PubMed]

88. Longatti, A. The Dual Role of Exosomes in Hepatitis A and C Virus Transmission and Viral Immune Activation. Viruses 2015, 7, 6707-6715. [CrossRef]

89. Hoshina, S.; Sekizuka, T.; Kataoka, M.; Hasegawa, H.; Hamada, H.; Kuroda, M.; Katano, H. Profile of Exosomal and Intracellular microRNA in Gamma-Herpesvirus-Infected Lymphoma Cell Lines. PLoS ONE 2016, 11, e0162574. [CrossRef]

90. Gallo, A.; Vella, S.; Miele, M.; Timoneri, F.; Di Bella, M.; Bosi, S.; Sciveres, M.; Conaldi, P.G. Global profiling of viral and cellular non-coding RNAs in Epstein-Barr virus-induced lymphoblastoid cell lines and released exosome cargos. Cancer Lett. 2017, 388, 334-343. [CrossRef]

91. Flanagan, J.; Middeldorp, J.; Sculley, T. Localization of the Epstein-Barr virus protein LMP 1 to exosomes. J. Gen. Virol. 2003, 84, 1871-1879. [CrossRef]

92. Temme, S.; Eis-Hubinger, A.M.; McLellan, A.D.; Koch, N. The herpes simplex virus-1 encoded glycoprotein B diverts HLA-DR into the exosome pathway. J. Immunol. 2010, 184, 236-243. [CrossRef] [PubMed]

93. Khan, G.; Ahmed, W.; Philip, P.S. Exosomes and Their Role in Viral Infections. In Novel Implications of Exosomes in Diagnosis and Treatment of Cancer and Infectious Diseases; InTech: London, UK, 2017. [CrossRef]

94. Gould, S.J.; Booth, A.M.; Hildreth, J.E. The Trojan exosome hypothesis. Proc. Natl. Acad. Sci. USA 2003, 100, 10592-10597. [CrossRef] [PubMed]

95. Ali, S.A.; Huang, M.B.; Campbell, P.E.; Roth, W.W.; Campbell, T.; Khan, M.; Newman, G.; Villinger, F.; Powell, M.D.; Bond, V.C. Genetic characterization of HIV type 1 Nef-induced vesicle secretion. AIDS Res. Hum. Retroviruses 2010, 26, 173-192. [CrossRef] [PubMed] 
96. Campbell, T.D.; Khan, M.; Huang, M.B.; Bond, V.C.; Powell, M.D. HIV-1 Nef protein is secreted into vesicles that can fuse with target cells and virions. Ethn. Dis. 2008, 18, S2-14-19. [PubMed]

97. Sami Saribas, A.; Cicalese, S.; Ahooyi, T.M.; Khalili, K.; Amini, S.; Sariyer, I.K. HIV-1 Nef is released in extracellular vesicles derived from astrocytes: Evidence for Nef-mediated neurotoxicity. Cell. Death. Dis. 2017, 8, e2542. [CrossRef] [PubMed]

98. Welsch, S.; Keppler, O.T.; Habermann, A.; Allespach, I.; Krijnse-Locker, J.; Krausslich, H.G. HIV-1 buds predominantly at the plasma membrane of primary human macrophages. PLoS Pathog. 2007, 3, e36. [CrossRef] [PubMed]

99. Blanchard, E.; Belouzard, S.; Goueslain, L.; Wakita, T.; Dubuisson, J.; Wychowski, C.; Rouille, Y. Hepatitis C virus entry depends on clathrin-mediated endocytosis. J. Virol. 2006, 80, 6964-6972. [CrossRef] [PubMed]

100. Meng, B.; Ip, N.C.; Prestwood, L.J.; Abbink, T.E.; Lever, A.M. Evidence that the endosomal sorting complex required for transport-II (ESCRT-II) is required for efficient human immunodeficiency virus-1 (HIV-1) production. Retrovirology 2015, 12, 72. [CrossRef]

101. Bruce, E.A.; Digard, P.; Stuart, A.D. The Rab11 pathway is required for influenza A virus budding and filament formation. J. Virol. 2010, 84, 5848-5859. [CrossRef]

102. Zou, X.; Gu, D.; Xing, X.; Cheng, Z.; Gong, D.; Zhang, G.; Zhu, Y. Human mesenchymal stromal cell-derived extracellular vesicles alleviate renal ischemic reperfusion injury and enhance angiogenesis in rats. Am. J. Transl. Res. 2016, 8, 4289-4299.

103. Zou, L.; Ma, X.; Lin, S.; Wu, B.; Chen, Y.; Peng, C. Bone marrow mesenchymal stem cell-derived exosomes protect against myocardial infarction by promoting autophagy. Exp. Ther. Med. 2019, 18, 2574-2582. [CrossRef]

104. Chen, T.S.; Lai, R.C.; Lee, M.M.; Choo, A.B.; Lee, C.N.; Lim, S.K. Mesenchymal stem cell secretes microparticles enriched in pre-microRNAs. Nucleic Acids. Res. 2010, 38, 215-224. [CrossRef]

105. Lai, R.C.; Tan, S.S.; Teh, B.J.; Sze, S.K.; Arslan, F.; de Kleijn, D.P.; Choo, A.; Lim, S.K. Proteolytic Potential of the MSC Exosome Proteome: Implications for an Exosome-Mediated Delivery of Therapeutic Proteasome. Int. J. Proteomics 2012, 2012, 971907. [CrossRef]

106. Bari, E.; Ferrarotti, I.; Saracino, L.; Perteghella, S.; Torre, M.L.; Corsico, A.G. Mesenchymal Stromal Cell Secretome for Severe COVID-19 Infections: Premises for the Therapeutic Use. Cells 2020, 9, 924. [CrossRef]

107. Sengupta, V.; Sengupta, S.; Lazo, A.; Woods, P.; Nolan, A.; Bremer, N. Exosomes Derived from Bone Marrow Mesenchymal Stem Cells as Treatment for Severe COVID-19. Stem Cells Dev. 2020, 29, 747-754. [CrossRef]

108. Lim, S.K.; Giebel, B.; Weiss, D.J.; Witwer, K.W.; Rohde, E. Re: “Exosomes Derived from Bone Marrow Mesenchymal Stem Cells as Treatment for Severe COVID-19" by Sengupta et al. Stem Cells Dev. 2020. [CrossRef]

109. Chong, S.Y.; Lee, C.K.; Huang, C.; Ou, Y.H.; Charles, C.J.; Richards, A.M.; Neupane, Y.R.; Pavon, M.V.; Zharkova, O.; Pastorin, G.; et al. Extracellular vesicles in cardiovascular diseases: Alternative biomarker sources, therapeutic agents, and drug delivery carriers. Int. J. Mol. Sci. 2019, 20, 3272. [CrossRef]

110. Loyer, X.; Zlatanova, I.; Devue, C.; Yin, M.; Howangyin, K.Y.; Klaihmon, P.; Guerin, C.L.; Kheloufi, M.; Vilar, J.; Zannis, K.; et al. Intra-Cardiac Release of Extracellular Vesicles Shapes Inflammation Following Myocardial Infarction. Circ. Res. 2018, 123, 100-106. [CrossRef]

111. Ribeiro-Rodrigues, T.M.; Laundos, T.L.; Pereira-Carvalho, R.; Batista-Almeida, D.; Pereira, R.; Coelho-Santos, V.; Silva, A.P.; Fernandes, R.; Zuzarte, M.; Enguita, F.J.; et al. Exosomes secreted by cardiomyocytes subjected to ischaemia promote cardiac angiogenesis. Cardiovasc. Res. 2017, 113, 1338-1350. [CrossRef]

112. New, S.E.; Aikawa, E. Role of extracellular vesicles in de novo mineralization: An additional novel mechanism of cardiovascular calcification. Arterioscler. Thromb. Vasc. Biol. 2013, 33, 1753-1758. [CrossRef]

113. Pokhrel, R.; Gerstman, B.S.; Hutcheson, J.D.; Chapagain, P.P. In Silico Investigations of Calcium Phosphate Mineralization in Extracellular Vesicles. J. Phys. Chem. B 2018, 122, 3782-3789. [CrossRef]

114. Hutcheson, J.D.; Goettsch, C.; Pham, T.; Iwashita, M.; Aikawa, M.; Singh, S.A.; Aikawa, E. Enrichment of calcifying extracellular vesicles using density-based ultracentrifugation protocol. J. Extracell. Vesicles 2014, 3, 1-12. [CrossRef]

115. Kapustin, A.N.; Davies, J.D.; Reynolds, J.L.; McNair, R.; Jones, G.T.; Sidibe, A.; Schurgers, L.J.; Skepper, J.N.; Proudfoot, D.; Mayr, M.; et al. Calcium regulates key components of vascular smooth muscle cell-derived matrix vesicles to enhance mineralization. Circ. Res. 2011, 109, e1-e12. [CrossRef] 
116. Goettsch, C.; Hutcheson, J.D.; Aikawa, M.; Iwata, H.; Pham, T.; Nykjaer, A.; Kjolby, M.; Rogers, M.; Michel, T.; Shibasaki, M.; et al. Sortilin mediates vascular calcification via its recruitment into extracellular vesicles. J. Clin. Investig. 2016, 126, 1323-1336. [CrossRef]

117. Genge, B.R.; Wu, L.N.; Wuthier, R.E. In vitro modeling of matrix vesicle nucleation: Synergistic stimulation of mineral formation by annexin A5 and phosphatidylserine. J. Biol. Chem. 2007, 282, 26035-26045. [CrossRef]

118. Chen, N.X.; O'Neill, K.D.; Chen, X.; Moe, S.M. Annexin-mediated matrix vesicle calcification in vascular smooth muscle cells. J. Bone Miner. Res. 2008, 23, 1798-1805. [CrossRef]

119. New, S.E.; Goettsch, C.; Aikawa, M.; Marchini, J.F.; Shibasaki, M.; Yabusaki, K.; Libby, P.; Shanahan, C.M.; Croce, K.; Aikawa, E. Macrophage-derived matrix vesicles: An alternative novel mechanism for microcalcification in atherosclerotic plaques. Circ. Res. 2013, 113, 72-77. [CrossRef]

120. Deng, L.; Peng, Y.; Jiang, Y.; Wu, Y.; Ding, Y.; Wang, Y.; Xu, D.; Fu, Q. Imipramine protects against bone loss by inhibition of osteoblast-derived microvesicles. Int. J. Mol. Sci. 2017, 18, 1013. [CrossRef]

121. Komatsu, M.; Waguri, S.; Chiba, T.; Murata, S.; Iwata, J.; Tanida, I.; Ueno, T.; Koike, M.; Uchiyama, Y.; Kominami, E.; et al. Loss of autophagy in the central nervous system causes neurodegeneration in mice. Nature 2006, 441, 880-884. [CrossRef] [PubMed]

122. Fussi, N.; Hollerhage, M.; Chakroun, T.; Nykanen, N.P.; Rosler, T.W.; Koeglsperger, T.; Wurst, W.; Behrends, C.; Hoglinger, G.U. Exosomal secretion of alpha-synuclein as protective mechanism after upstream blockage of macroautophagy. Cell Death Dis. 2018, 9, 757. [CrossRef]

123. Asai, H.; Ikezu, S.; Tsunoda, S.; Medalla, M.; Luebke, J.; Haydar, T.; Wolozin, B.; Butovsky, O.; Kugler, S.; Ikezu, T. Depletion of microglia and inhibition of exosome synthesis halt tau propagation. Nat. Neurosci. 2015, 18, 1584-1593. [CrossRef]

124. Lee, J.A.; Beigneux, A.; Ahmad, S.T.; Young, S.G.; Gao, F.B. ESCRT-III dysfunction causes autophagosome accumulation and neurodegeneration. Curr. Biol. 2007, 17, 1561-1567. [CrossRef]

125. Payrastre, B.; Missy, K.; Giuriato, S.; Bodin, S.; Plantavid, M.; Gratacap, M. Phosphoinositides: Key players in cell signalling, in time and space. Cell. Signal. 2001, 13, 377-387. [CrossRef]

126. Janmey, P.A.; Lindberg, U. Cytoskeletal regulation: Rich in lipids. Nat. Rev. Mol. Cell. Biol. 2004, 5, 658-666. [CrossRef]

127. De Craene, J.O.; Bertazzi, D.L.; Bar, S.; Friant, S. Phosphoinositides, Major Actors in Membrane Trafficking and Lipid Signaling Pathways. Int. J. Mol. Sci. 2017, 18, 634. [CrossRef]

128. Audhya, A.; Foti, M.; Emr, S.D. Distinct roles for the yeast phosphatidylinositol 4-kinases, Stt4p and Pik1p, in secretion, cell growth, and organelle membrane dynamics. Mol. Biol. Cell 2000, 11, 2673-2689. [CrossRef]

129. Kihara, A.; Noda, T.; Ishihara, N.; Ohsumi, Y. Two distinct Vps34 phosphatidylinositol 3-kinase complexes function in autophagy and carboxypeptidase Y sorting in Saccharomyces cerevisiae. J. Cell. Biol. 2001, 152, 519-530. [CrossRef]

130. Obara, K.; Ohsumi, Y. PtdIns 3-Kinase Orchestrates Autophagosome Formation in Yeast. J. Lipids 2011, 2011, 498768. [CrossRef] [PubMed]

131. Gruenberg, J.; Stenmark, H. The biogenesis of multivesicular endosomes. Nat. Rev. Mol. Cell. Biol. 2004, 5, 317-323. [CrossRef]

132. van Weering, J.R.; Verkade, P.; Cullen, P.J. SNX-BAR proteins in phosphoinositide-mediated, tubular-based endosomal sorting. Semin. Cell. Dev. Biol. 2010, 21, 371-380. [CrossRef] [PubMed]

133. Boal, F.; Mansour, R.; Gayral, M.; Saland, E.; Chicanne, G.; Xuereb, J.M.; Marcellin, M.; Burlet-Schiltz, O.; Sansonetti, P.J.; Payrastre, B.; et al. TOM1 is a PI5P effector involved in the regulation of endosomal maturation. J. Cell. Sci. 2015, 128, 815-827. [CrossRef]

134. Ferguson, C.J.; Lenk, G.M.; Meisler, M.H. Defective autophagy in neurons and astrocytes from mice deficient in PI(3,5)P2. Hum. Mol. Genet. 2009, 18, 4868-4878. [CrossRef]

135. Cao, Q.; Yang, Y.; Zhong, X.Z.; Dong, X.P. The lysosomal Ca2+ release channel TRPML1 regulates lysosome size by activating calmodulin. J. Biol. Chem. 2017, 292, 8424-8435. [CrossRef]

136. Hong, N.H.; Qi, A.; Weaver, A.M. PI(3,5)P2 controls endosomal branched actin dynamics by regulating cortactin-Actin interactions. J. Cell Biol. 2015, 210, 753-769. [CrossRef]

137. Whitley, P.; Reaves, B.J.; Hashimoto, M.; Riley, A.M.; Potter, B.V.; Holman, G.D. Identification of mammalian Vps24p as an effector of phosphatidylinositol 3,5-bisphosphate-dependent endosome compartmentalization. J. Biol. Chem. 2003, 278, 38786-38795. [CrossRef] 
138. Essandoh, K.; Yang, L.; Wang, X.; Huang, W.; Qin, D.; Hao, J.; Wang, Y.; Zingarelli, B.; Peng, T.; Fan, G.C. Blockade of exosome generation with GW4869 dampens the sepsis-induced inflammation and cardiac dysfunction. Biochim. Biophys. Acta 2015, 1852, 2362-2371. [CrossRef]

139. Guo, B.B.; Bellingham, S.A.; Hill, A.F. Stimulating the release of exosomes increases the intercellular transfer of prions. J. Biol. Chem. 2016, 291, 5128-5137. [CrossRef] [PubMed]

140. Wang, J.; Yeung, B.Z.; Cui, M.; Peer, C.J.; Lu, Z.; Figg, W.D.; Guillaume Wientjes, M.; Woo, S.; Au, J.L. Exosome is a mechanism of intercellular drug transfer: Application of quantitative pharmacology. J. Control Release 2017, 268, 147-158. [CrossRef]

141. Hatzidaki, E.; Vlachou, I.; Elka, A.; Georgiou, E.; Papadimitriou, M.; Iliopoulos, A.; Papasotiriou, I. The use of serum extracellular vesicles for novel small molecule inhibitor cell delivery. Anticancer Drugs 2019, 30, 271-280. [CrossRef]

142. Kim, M.S.; Haney, M.J.; Zhao, Y.; Mahajan, V.; Deygen, I.; Klyachko, N.L.; Inskoe, E.; Piroyan, A.; Sokolsky, M.; Okolie, O.; et al. Development of exosome-encapsulated paclitaxel to overcome MDR in cancer cells. Nanomedicine 2016, 12, 655-664. [CrossRef] [PubMed]

143. Haney, M.J.; Klyachko, N.L.; Zhao, Y.; Gupta, R.; Plotnikova, E.G.; He, Z.; Patel, T.; Piroyan, A.; Sokolsky, M.; Kabanov, A.V.; et al. Exosomes as drug delivery vehicles for Parkinson's disease therapy. J. Control Release 2015, 207, 18-30. [CrossRef] [PubMed]

144. Alvarez-Erviti, L.; Seow, Y.; Yin, H.; Betts, C.; Lakhal, S.; Wood, M.J. Delivery of siRNA to the mouse brain by systemic injection of targeted exosomes. Nat. Biotechnol. 2011, 29, 341-345. [CrossRef]

145. Melling, G.E.; Carollo, E.; Conlon, R.; Simpson, J.C.; Carter, D.R.F. The Challenges and Possibilities of Extracellular Vesicles as Therapeutic Vehicles. Eur. J. Pharm. Biopharm. 2019, 144, 50-56. [CrossRef]

146. Domotor, E.; Abbott, N.J.; Adam-Vizi, V. Na+-Ca2+ exchange and its implications for calcium homeostasis in primary cultured rat brain microvascular endothelial cells. J. Physiol. 1999, 515, 147-155. [CrossRef] [PubMed]

147. Savina, A.; Furlán, M.; Vidal, M.; Colombo, M.I. Exosome release is regulated by a calcium-dependent mechanism in K562 cells. J. Biol. Chem. 2003, 278, 20083-20090. [CrossRef] [PubMed]

148. Gangoda, L.; Mathivanan, S. Cortactin enhances exosome secretion without altering cargo. J. Cell Biol. 2016, 214, 129-131. [CrossRef]

149. Ibrahim, A.G.; Cheng, K.; Marban, E. Exosomes as critical agents of cardiac regeneration triggered by cell therapy. Stem Cell Reports 2014, 2, 606-619. [CrossRef]

150. Arenz, C.; Thutewohl, M.; Block, O.; Waldmann, H.; Altenbach, H.J.; Giannis, A. Manumycin A and its analogues are irreversible inhibitors of neutral sphingomyelinase. Chembiochem 2001, 2, 141-143. [CrossRef]

151. Sexton, R.E.; Mpilla, G.; Kim, S.; Philip, P.A.; Azmi, A.S. Ras and exosome signaling. Semin. Cancer Biol. 2019, 54, 131-137. [CrossRef]

152. Phuyal, S.; Hessvik, N.P.; Skotland, T.; Sandvig, K.; Llorente, A. Regulation of exosome release by glycosphingolipids and flotillins. FEBS J. 2014, 281, 2214-2227. [CrossRef] [PubMed]

153. Hofmann, K.; Tomiuk, S.; Wolff, G.; Stoffel, W. Cloning and characterization of the mammalian brain-specific, Mg2+-dependent neutral sphingomyelinase. Proc. Natl. Acad. Sci. USA 2000, 97, 5895-5900. [CrossRef] [PubMed]

154. Khan, S.; Jutzy, J.M.S.; Aspe, J.R.; McGregor, D.W.; Neidigh, J.W.; Wall, N.R. Survivin is released from cancer cells via exosomes. Apoptosis 2011, 16, 1-12. [CrossRef] [PubMed]

155. Miyoshi, H.; Umeshita, K.; Sakon, M.; Imajoh-Ohmi, S.; Fujitani, K.; Gotoh, M.; Oiki, E.; Kambayashi, J.; Monden, M. Calpain activation in plasma membrane bleb formation during tert-butyl hydroperoxide-induced rat hepatocyte injury. Gastroenterology 1996, 110, 1897-1904. [CrossRef] [PubMed]

156. Abid Hussein, M.N.; Boing, A.N.; Sturk, A.; Hau, C.M.; Nieuwland, R. Inhibition of microparticle release triggers endothelial cell apoptosis and detachment. Thromb. Haemost. 2007, 98, 1096-1107. [CrossRef]

157. Hessvik, N.P.; Øverbye, A.; Brech, A.; Torgersen, M.L.; Jakobsen, I.S.; Sandvig, K.; Llorente, A. PIKfyve inhibition increases exosome release and induces secretory autophagy. Cell. Mol. Life Sci. 2016, 73, 4717-4737. [CrossRef]

(C) 2020 by the authors. Licensee MDPI, Basel, Switzerland. This article is an open access article distributed under the terms and conditions of the Creative Commons Attribution (CC BY) license (http://creativecommons.org/licenses/by/4.0/). 